\title{
Pengaruh Lingkungan dan Kesejahteraan terhadap Etos Kerja Karyawan PTPN I Pulau Tiga di Aceh Tamiang
}

\author{
Riny Chandra \\ Fakultas Ekonomi, Universitas Samudra \\ e-mail: rini.chandra@unsam.ac.id
}

\begin{abstract}
Abstrak
Tujuan dari penelitian ini adalah untuk mengetahui besarnya pengaruh lingkungan dan kesejahteraan terhadap etos kerja karyawan PTPN I Pulau Tiga di Aceh Tamiang. Adapun Sampel yang digunakan adalah sebanyak 56 orang. Tehnik Sampling dalam penelitian ini menggunakan sampling jenuh dengan metode analisis data menggunakan model persamaan regresi linear berganda. pembuktian hipotesis dengan menggunakan uji $t$, uji $F$ dan koefisien determinasi $\left(R^{2}\right)$ serta di hitung dengan menggunakan program SPSS versi 23,0. Hasil uji $t$ untuk variabel lingkungan dan variabel kesejahteraan berpengaruh positif dan signifikan terhadap etos kerja PTPN I Pulau Tiga di Aceh Tamiang. Sedangkan dari hasil uji $F$ untuk variabel lingkungan kerja dan variabel kesejahteraan secara simultan berpengaruh positif dan signifikan terhadap etos kerja. Dengan demikian hipotesis dalam penelitian ini diterima.
\end{abstract}

Kata Kunci: Lingkungan Kerja, Kesejahteraan dan Etos Kerja Karyawan.

\section{PENDAHULUAN}

Kebun Pulau Tiga merupakan salah satu unit usaha agrobisnis PT. Perkebunan Nusantara I yang telah berdiri sejak tahun 1976 dan memiliki HGU seluas 5.561 ha, terbagi atas 8 afdeling yang hamparan arealnya dikawasan Kabupaten Aceh Tamiang (Kecamatan Kejuruan Muda, Kecamatan Tamiang Hulu dan Kecamatan Bandar Pusaka) dengan ketinggian 10-125 meter di atas permukaan laut.Tantangan yang harus dihadapi oleh PTPN I Pulau Tiga saat ini adalah kebijaksanaan untuk meningkatkan kesejahteraan kehidupan karyawan. Kesejahteraan ini menyangkut kesejahteraan keluarga, kebutuhan olahraga, kesenian, rekreasi, keagamaan dan hubungan sosial antara karyawan. Pemberian kesejahteraan harus dikembangkan dalam kerangka hubungan industrial yang harmonis antara pengusaha, buruh dan pemerintah. Hubungan industrial adalah hubungan semua pihak yang terkait atau berkepentingan atas proses produksi barang atau jasa di suatu perusahaan. Oleh karena itu ketiganya harus bekerja sama, saling menguntungkan dan beritikad baik. Pemberian balas jasa kepada karyawan, baik secara langsung maupun tidak langsung dimaksudkan untuk meningkatkan kesejahteraan karyawan dan pada akhirnya untuk meningkatkan produktivitas karyawan.

Dalam kondisi sekarang ini usaha menciptakan kerja yang sehat tidak hanya terbatas pada tempat kerja saja, akan tetapi sudah diperluas menjadi lingkungan. Lingkungan kerja dapat diartikan sebagai segala sesuatu yang ada disekitar para pekerja dan yang dapat mempengaruhi dalam menjalankan tugas-tugas yang dibebankan. Lingkungan kerja yang aman dan sehat sangat diperlukan oleh setiap orang karena dengan kondisi kerja yang nyaman seseorang dapat bekerja secara tenang, sehingga hasil kerjanya juga dapat diharapkan memenuhi standar yang telah ditetapkan. Lingkungan kerja telah berubah menjadi suatu lingkungan yang mempunyai ikatan batin yang kuat antara orang-orang di dalam lingkungan itu, karena pada hakekatnya lingkungan kerja itu telah menjadi rumah tangga yang kedua bagi pekerja.

Dalam hal ini PTPN I Pulau Tiga dan karyawan secara bersama-sama menciptakan kondisi yang kondusif untuk mencapai 
pemahaman yang dimaksud. Berdasarkan observasi sementara peneliti, karyawan PTPN I Pulau Tiga merasakan adanya hal-hal yang tidak menarik dan memberinya ketidakpuasan, yaitu berupa lingkungan kerja yang masih kurang nyaman, seperti ruang kerja yang sempit dan membuat karyawan sulit bergerak, suhu udara yang panas karena tidak disediakan AC (Air Conditioner) tetapi hanya kipas angin yang tidak di semua ruangan berfungsi dengan baik, air dan udara di tempat kerja yang tercemar, seperti polusi air yang berasal dari limbah pabrik yang mencemari air di lingkungan kantor serta polusi udara yang berasal dari asap pabrik karena kantor berada dekat dengan pabrik, sehingga karyawan sering mengalami sakit kepala, mata perih, kelelahan, cepat marah dan depresi serta hubungan yang kurang fleksibel/kaku baik antar sesama rekan kerja maupun antara atasan dengan bawahan.

Selain itu karyawan PTPN I Pulau Tiga juga mengeluh tentang tingkat kesejahteraan mereka yang masih rendah. Hal itu dapat dilihat dari uang lembur yang masih tidak sesuai dengan kesepakatan yang akan dibayar berdasarkan hitungan jam per harinya serta pembayarannya sering mengalami keterlambatan, kemudian perumahan yang diberikan oleh PTPN I Pulau Tiga yang tidak layak, fasilitas air minum yang kurang bersih, pemberian dana pensiun yang masih rendah dan sangat jarang mengadakan program rekreasi sehingga karyawan merasa jenuh. Hal-hal tersebut tentu saja menyebabkan etos kerja karyawan menjadi rendah.

\section{Perumusan Masalah}

1. Bagaimanakah pengaruh lingkungan dan kesejahteraan secara parsial terhadap etos kerja karyawanPTPN I Pulau Tiga?

2. Bagaimanakah pengaruh lingkungan dan kesejahteraan secara simultan terhadap etos kerja karyawanPTPN I Pulau Tiga?

\section{Tujuan Penelitian}

berikut:

Tujuan penelitian ini adalah sebagai

1. Untuk mengetahui besarnya pengaruh lingkungan dan kesejahteraan secara parsial terhadap etos kerja karyawanPTPN I Pulau Tiga.

2. Untuk mengetahui besarnya pengaruh lingkungan dan kesejahteraan secara simultan terhadap etos kerja karyawanPTPN I Pulau Tiga.

\section{Lingkungan Kerja}

Lingkungan kerja dalam suatu perusahaan sangat penting untuk diperhatikan oleh manajemen. Walaupun lingkungan kerja tidak melaksanakan proses produksi dalam suatu perusahaan, namun lingkungan kerja mempunyai pengaruh langsung terhadap para karyawan yang melaksanakan proses produksi tersebut. Lingkungan kerja adalah suasana dimana karyawan melakukan aktivitas setiap harinya. Nitisemito (2008) mengatakan bahwa lingkungan kerja adalah segala sesuatu yang ada disekitar para pekerja dan yang dapat mempengaruhi dalam menjalankan tugastugas yang dibebankan. Sedangkan Umar (2009) mengatakan bahwa lingkungan adalah segala benda, kondisi keadaan dan pengaruh yang terdapat dalam ruang yang ditempati karyawan dan mempengaruhi karyawan.

Selanjutnya menurut Isyandi (2009), lingkungan kerja adalah sesuatu yang ada di lingkungan para pekerja yang dapat mempengaruhi dirinya dalam menjalankan tugas seperti temperatur, kelembapan, ventilasi, penerangan, kegaduhan, kebersihan tempat kerja dan memadai tidaknya alat-alat perlengkapan kerja.Simanjuntak (2008), menyatakan bahwasannya lingkungan kerja sebagai keseluruhan alat perkakas yang dihadapi, lingkungan sekitarnya dimana seorang bekerja, metode kerjanya, sebagai pengaruh kerjanya baik sebagai perorangan maupun sebagai kelompok.

Dari beberapa definisi di atas dapat disimpulkan bahwa lingkungan kerja adalah segala sesuatu yang ada disekitar para pekerja/karyawan yang dapat mempengaruhi dirinya dalam melaksanakan pekerjaannya sehingga akan diperoleh hasil kerja yang maksimal, dimana dalam lingkungan kerja tersebut terdapat fasilitas kerja yang mendukung karyawan dalam penyelesaian tugas yang dibebankan kepada karyawan guna 
meningkatkan kinerja karyawan dalam suatu perusahaan.

\section{Aspek Lingkungan Kerja}

Lingkungan kerja dapat dibagi menjadi beberapa bagian atau bisa disebut juga aspek pembentuk lingkungan kerja (Simanjuntak, 2008).Bagian-bagian itu bisa diuraikan sebagai berikut:

1. Pelayanan kerja

Pelayanan karyawan merupakan aspek terpenting yang harus dilakukan oleh setiap perusahaan terhadap tenaga kerja. Pelayanan yang baik dari perusahaan akan membuat karyawan lebih bergairah dalam bekerja, mempunyai rasa tanggung jawab dalam menyelesaikan pekerjaannnya serta dapat terus mennjaga nama baik perusahaan melalui produktivitas kerjanya dan tingkah lakunya. Pada umumnya pelayanan karyawan meliputi beberapa hal, yaitu: (a). Pelayanan makan dan minum. (b). Pelayanan kesehatan. (c).Pelayanan kamar kecil/kamar mandi ditempat kerja, dan sebagainya.

2. Kondisi Kerja

Kondisi kerja karyawan sebaiknya diusahakan oleh manajemen perusahaan sebaik mungkin agar timbul rasa aman dalam bekerja untuk karyawannya, kondisi kerja ini meliputi penerangan yang cukup, suhu udara yang tepat, kebisingan yang dapat dikendalikan, pengaruh warna, ruang gerak yang diperlukan dan keamanan kerja karyawan.

3. Hubungan karyawan

Hubungan karyawan akan sangat menentukan dalam menghasilkan produktivitas kerja. Hal ini disebabkan karena adanya hubungan antara motivasi serta semangat dan kegairahan kerja dengan hubungan yang kondusif antar sesama karyawan dalam bekerja, ketidak serasian hubungan antara karyawan dapat menurunkan motivasi dan kegairahan yang akibatnya akan dapat menurunkan produktivitas kerja.
Faktor-faktor yang Mempengaruhi Lingkungan Kerja

Menurut Siagian (2009), untuk menciptakan lingkungan kerja yang baik ada beberapa hal yang harus diperhatikan, yaitu:

1. Bangunan tempat kerja.

2. Ruang kerja yang lega.

3. Ventilasi pertukaran udara.

4. Tersedianya tempat-tempat ibadah keagamaan.

5. Tersedianya sarana angkutan khusus maupun umum untuk karyawan yang nyaman dan mudah.

Sedangkan Suwatno dan Priansa (2011) mengatakan bahwa secara umum lingkungan kerja terdiri dari:

1. Faktor Lingkungan Fisik, adalah lingkungan yang berada disekitar pekerja itu sendiri. Kondisi di lingkungan kerja dapat mempengaruhi kepuasan kerja karyawan yang meliputi:Rencana Ruang Kerja,Rancangan Pekerjaan,Kondisi Lingkungan Kerja, Tingkat Visual Privacy dan Acoustical Privacy.

2. Faktor Lingkungan Psikis

Faktor lingkungan psikis adalah hal-hal yang menyangkut dengan hubungan sosial dankeorganisasian. Kondisi psikis yang mempengaruhi kepuasan kerja karyawan adalah:

a. Pekerjaan yang Berlebihan.

b. Sistem Pengawasan yang Buruk.

c. Frustasi.

d. Perubahan-Perubahan Dalam Segala Bentuk.

e. Perselisihan Antara Pribadi dan Kelompok.

Adapun Indikator Lingkungan Kerja, menurut Gie dalam Nuraini (2013), adalah sebagai berikut: (1) Cahaya. (2) Warna. (3) Udara. (4) Suara

\section{Kesejahteraan}

Heijdrachman dan Husnan (2009) mengatakan bahwa banyak istilah yang dipergunakan untuk program-program pelayanan karyawan, ada yang menggunakan istilah "Jaminan Sosial" atau program "Kesejahtreraan Karyawan" dan lain sebagainya. Demikian juga bentuk program ini bermacam-macam seperti tunjangan 
pensiun, asuransi jiwa, pemberian pinjaman, pelayanan kesehatan dan lain sebagainya. Kesejahteraan merupakan suatu bentuk usaha yang digunakan oleh perusahaan dalam rangka meningkatkan semangat kerja karyawan. Pelayanan kesejahteraan merupakan rangkaian pemberian tunjangan dan fasilitas-fasilitas dalam bentuk tertentu kepada karyawan di luar gaji, biasanya berupa transportasi, uang lembur, cuti, kantin, asuransi, jamsostek dan sebagainya.Pelayanan kesejahteraan karyawan tersebut dimaksudkan untuk memberikan keseimbangan dalam memperoleh keamanan dari segi fisik dan psikis bagi karyawan beserta keluarganya serta menciptakan ketenangan, semangat kerja, dedikasi, disiplin dan sikap loyal karyawan terhadap perusahaan, sehingga labour turnover relatif rendah.

Hasibuan (2010) mengatakan bahwa kesejahteraan karyawan adalah balas jasa pelengkap (material dan nonmaterial) yang diberikan berdasarkan kebijaksanaan, bertujuan mempertahankan kondisi fisik dan mental karyawan, agar produktivitas kerja karyawan meningkat. Wursanto (2009) mengemukakan bahwa kesejahteraan sosial atau jaminan sosial adalah suatu bentuk pemberian penghasilan, baik dalam bentuk materi ataupun non materi, yang diberikan oleh perusahaan pada karyawan untuk selama masa pengabdiannya ataupun setelah berhenti karena pensiun atau karena lanjut usia dalam usaha pemenuhan kebutuhan, baik kebutuhan materi atau non materi, kepada para karyawan dengan tujuan untuk memberikan semangat atau dorongan kepada para karyawan.

Dari pendapat para ahli di atas, maka kesejahteraan merupakan usaha dari pemimpin perusahaan untuk merangsang dan meningkatkan semangat kerja karyawannya, sehingga produktivitas karyawan juga meningkat dan tujuan dari suatu perusahaan dapat tercapai.

\section{Program-progam \\ Karyawan}

Kesejahteraan

Hasibuan (2010) mengatakan bahwa program kesejahteraan karyawan dirancang dan diselenggarakan untuk memelihara karyawan, meningkatkan loyalitas kerja serta melindungi keamanan setiap karyawan. Perusahaan menyadari tidak ada yang abadi didunia ini oleh sebab itu sebaiknya perusahaan mempunyai pedoman dalam menghadapi situasi dan kondisi yang tidak pasti. Salah satu cara yang dilakukan oleh perusahaan, yaitu membentuk suatu program pelayanan kesejahteraan karyawan yang meliputi:

1. Asuransi

Program asuransi bertujuan untuk melindungi setiap karyawan dari hal-hal tidak diinginkan yang dapat terjadi setiap saat. Asuransi biasanya dapat berbentuk asuransi jiwa, kesehatan dan kecelakaan. Dalam hal ini perusahaan dapat melakukan kerjasama dengan perusahaan asuransi untuk menanggung asuransi setiap karyawan.

2. Pemberian Fasilitas

Hubungan pelayanan yang bersifat memberikan fasilitas adalah kegiatankegiatan yang secara normal perlu diperhatikan oleh setiap karyawan dalam menjalani pekerjaannya. Program pemberian fasilitas yang dilakukan oleh perusahaan dapat berbentuk:
a. Penyediaan kantin
b. Fasilitas perumahan
c. Kesehatan
d. Fasilitas pendidikan
e. Fasilitas ibadah
f. Fasilitas pembelian
g. Penasehat keuangan
h. Pemberian kredit

3. Pensiun

Pemberian pensiun berarti perusahaan memberikan sejumlah uang tertentu sebagai balas jasa atas usaha yang telah diberikan karyawan terhadap perusahaan selama bekerja. Besarnya uang pensiun yang diterima oleh karyawan biasanya dibedakan atas tingkat jabatan seorang karyawan dan lamanya bekerja. Pensiun dapat terjadi karena usia yang telah melewati masa produktif, diberhentikan atau karena meninggal dunia.

4. Program Rekreasi

Setiap orang memerlukan rekreasi atau hiburan di dalam menjalani kehidupannya, karena suatu saat akan 
mancapai titik jenuh dimana ia merasa bosan atau jenuh dalam mengerjakam segala sesuatu yang bersifat rutinitas. Maka pada saat itulah mereka memerlukan hiburan/rekreasi untuk penyegaran atau refreshing. Adapun program-program rekreasi ini dapat di kelompokkan menjadi beberapa bagian:

a. Kegiatan olahraga

Kegiatan ini dimaksudkan untuk sekedar memelihara kesehatan (bersifat internal) yang melibatkan keikutsertaan sejumlah besar karyawan atau bisa juga untuk mengejar prestasi (bersifat varsity) dimana suatu tim dipilih untuk mewakili perusahaan. Dengan memelihara kesehatan para karyawan, berarti perusahaan juga akan mendapatkan semangat kerja yang maksimal dari para karyawannya. Di lain pihak bila perusahaan mempunyai klub olahraga yang berprestasi, maka dapat digunakan sebagai publikasi bagi perusahaan.

b. Kegiatan sosial

Manusia sebagai makhluk sosial, selalu berhubungan dengan orang lain dan memiliki ketergantungan antara yang satu dengan yang lainnya. Sebagai makhluk sosial, manusia biasanya berkelompok dan senang melakukan sesuatu bersamasama atau dalam satu kelompok. Hal ini dapat menimbulkan suasana akrab di antara karyawan, sehingga dapat menunjang semangat dan moral kerja karyawan.

\section{Prinsip-prinsip Program Pelayanan Kesejahteraan Karyawan}

Menurut Husnan (2010), prinsipprinsip dari program pelayanan kesejahteraan karyawan adalah sebagai berikut: (1). Pelayanan hendaknya diarahkan untuk memuaskan kebutuhan yang sebenarnya. (2). Pelayanan hendaknya dibatasi pada kegiatan yang lebih efektif dan dijalankan secara kompak. (3). Pelayanan haruslah mengunakan dasar yang seluas mungkin. (4). Biaya program pelayanan ini hendaknya bisa dihitung dan provisinya ditentukan secara jelas untuk dasar pembelajaran.

\section{Indikator Tingkat Kesejahteraan}

Manullang (2009) mengatakan bahwa indikator tingkat kesejahteraan adalah sebagai berikut: (1). Pendapatan selama satu bulan. (2). Kepuasan terhadap pendapatan. (3). Konsumsi/pengeluaran per bulan. (4). Persepsi terhadap kecukupan gaji untuk memenuhi kebutuhan hidup. (5). Kesehatan dan keselamatan kerja. (6). Pemanfaatan dan tanggapan terhadap kesejahteraan lainnya (mess dan alat transportasi berupa bus antar jemput). (7). Kehidupan beragama. (8). Kemudahan melakukan olahraga. (9). Status sosial. (10).Rasa betah selama bekerja di perusahaan. (11). Rasa aman dari gangguan kejahatan di tempat kerja maupun disekitar tempat kerja.

\section{Etos Kerja}

Menurut Sinamo (2011), etos kerja dapat diartikan sebagai doktrin tentang kerja yang diyakini oleh seseorang atau sekelompok orang sebagai baik dan benar yang mewujud nyata secara khas dalam perilaku kerja mereka. Sedangkan menurut Hasibuan (2010), etos kerja adalah sebagai semangat kerja yang didasari oleh nilai-nilai atau norma-norma tertentu. Husnan (2010) menyatakan bahwa etos kerja adalah suatu semangat kerja yang dimiliki oleh masyarakat untuk mampu bekerja lebih baik guna memperoleh nilai hidup mereka. Etos kerja menentukan penilaian manusia yang diwujudkan dalam suatu pekerjaan.

Husnan (2010) mengatakan bahwa suatu individu atau kelompok masyarakat dapat dikatakan memiliki etos kerja yang tinggi, apabila menunjukkan tanda-tanda sebagai berikut:

1. Mempunyai penilaian yang sangat positif terhadap hasil kerja manusia.

2. Menempatkan pandangan tentang kerja, sebagai suatu hal yang amat luhur bagi eksistensi manusia.

3. Kerja yang dirasakan sebagai aktivitas yang bermakna bagi kehidupan manusia. 
4. Kerja dihayati sebagai suatu proses yang membutuhkan ketekunan dan sekaligus sarana yang penting dalam mewujudkan cita-cita.

5. Kerja dilakukan sebagai bentuk ibadah.

\section{Faktor-faktor yang Mempengaruhi Etos Kerja}

Menurut Sinamo (2011), terdapat beberapa faktor internal yang mempengaruhi etos kerja, yaitu:

1. Usia, pekerja yang berusia di bawah 30 tahun memiliki etos kerja lebih tinggi daripada pekerja yang berusia di atas 30 tahun.

2. Jenis kelamin, wanita memiliki etos kerja yang lebih tinggi dari pada pria.

3. Latar belakang pendidikan, etos kerja tertinggi dimiliki oleh pekerja dengan latar belakang pendidikan S1 dan terendah dimiliki oleh pekerja dengan latar belakang pendidikan SMU.

4. Lama bekerja, pekerja yang sudah bekerja selama 1-2 tahun memiliki etos kerja yang lebih tinggi daripada yang bekerja dibawah 1 tahun. Semakin lama individu bekerja, semakin tinggilah kemungkinan individu untuk memperoleh kesempatan untuk mengembangkan dan menggunakan kapasitasnya dan memperoleh peluang untuk pertumbuhan dan mendapatkan jaminan. Kedua hal tersebut akan membentuk persepsi seseorang terhadap kualitas kehidupan bekerjanya.

Selain faktor-faktor internal di atas, terdapat pula faktor eksternal yang mempengaruhi etos kerja karyawan, yaitu:

1. Budaya, masyarakat yang memiliki sistem budaya maju akan memiliki etos kerja yang lebih tinggi daripada masyarakat yang memiliki sistem budaya yang tidak maju.

2. Sosial Politik, etos kerja yang dimiliki suatu masyarakat sangat tergantung kepada ada tidaknya sturktur politik yang mendorong masyarakat untuk bekerja keras dan dapat menikmati hasil kerja keras mereka dengan penuh.
3. Kondisi Lingkungan Geografis, lingkungan alam yang mendukung, mempengaruhi manusia yang ada di dalamnya melakukan usaha untuk dapat mengelola dan mengambil manfaat dan bahkan dapat mengundang pendatang untuk turut mencari penghidupan di lingkungan tersebut. Kondisi lingkungan inilah yang akan mempengaruhi bagaimana persepsi seseorang terhadap kualitas kehidupan bekerjanya.

4. Struktur Ekonomi, tinggi rendahnya etos kerja yang dimiliki masyarakat, dipengaruhi oleh ada atau tidaknya stuktur ekonomi yang mampu memberikan insentif bagi anggota masyarakat untuk bekerja keras dan menikmati hasil kerja keras mereka dengan penuh.

Indikator Etos Kerja menurut Husnan (2010) adalah sebagai berikut: (1). Kepedulian terhadap situasi dan kondisi di sekitarnya. (2). Pekerjaannya merupakan suatu kesenangan baginya. (3). Merasa puas dengan hasil kerjanya.(4). Taat dengan peraturan yang telah ditetapkan.(5). Bersedia menginstropeksi kesalahan dalam setiap pekerjaannya.

\section{METODE PENELITIAN \\ Populasi dan Sampel}

Populasi dalam penelitian ini adalah semua karyawan di PTPN I Pulau Tiga yang berjumlah 56 orang. Teknik pengambilan sampel pada penelitian ini adalah teknik sampling jenuh, yaitu teknik penentuan sampel bila semua anggota populasi digunakan sebagai sampel. Oleh karena itu jumlah sampel penelitian ini adalah 56 orang.

\section{Metode Pengumpulan Data}

Adapun penelitian lapangan ini dilakukan dengan cara:

1. Observasi dalam penelitian ini salah satu teknik pengumpulan data dilakukan dengan pengamatan, yaitu peneliti secara langsung mengamati jalannya kegiatan operasional PTPN I Pulau Tiga.

2. Wawancara adalah cara pengumpulan data dengan mengadakan tanya jawab 
langsung kepada objek yang diteliti atau kepada perantara yang mengetahui persoalan dari objek yang sedang diteliti (Sugiyono, 2008).

3. Kuesioner dengan cara memberikan daftar pertanyaan untuk dijawab secara tertulis olehresponden (Sugiyono, 2008). Pengukuran persepsi responden ini menggunakan skala likert.

Penelitian Kepustakaan merupakan teknik pengumpulan data dengan mengadakan studi penelaahan terhadap buku-buku, literatur-literatur, catatan-catatan dan laporanlaporan yang ada hubungannya dengan masalah yang diteliti.

\section{Metode Analisis Data}

Adapun penelitian ini bertujuan untuk mengetahui seberapa besar pengaruh Lingkungan dan Kesejahteraan terhadap variabel dependen dalam hal ini Etos Kerja, maka digunakan uji statistik linear berganda. Dengan model persamaan regresi linear berganda, sebagai berikut:

$\mathrm{Y}=a+\mathrm{b}_{1} \mathrm{X}_{1}+\mathrm{b}_{2} \mathrm{X}_{2}+\ldots+\mathrm{b}_{\mathrm{n}} \mathrm{X}_{\mathrm{n}}+\mathrm{e}$

\section{Dimana:}

$\begin{array}{ll}\mathrm{Y} & =\text { Dependent Variable } \\ a & =\text { Intercept } / \text { Konstanta } \\ \mathrm{X}_{1}, \mathrm{X}_{2}, \mathrm{X}_{\mathrm{n}} & =\text { Independent Variable } \\ \mathrm{b}_{1}, \mathrm{~b}_{2}, \mathrm{~b}_{\mathrm{n}} & =\text { Koefisien regresi variabel } \\ & \text { bebas } \\ \mathrm{e} & =\text { Error term }\end{array}$

Persamaan tersebut akan diformulasikan menjadi:

$\mathrm{EK}=a+\mathrm{b}_{1} \mathrm{LK}+\mathrm{b}_{2} \mathrm{KS}$

Dimana:

\begin{tabular}{|c|c|}
\hline EK & $=$ Etos Kerja \\
\hline LK & $=$ Lingkungan \\
\hline $\mathrm{KS}$ & $=$ Kesejahteraan \\
\hline$a$ & $=$ Konstanta \\
\hline $\mathrm{b}$ & $=$ Koefisien variabel bebas \\
\hline
\end{tabular}

\section{HASIL ANALISIS}

Pengaruh Lingkungan dan Kesejahteraan terhadap Etos Kerja

Analisis data dalam penelitian ini menggunakan regresi linear berganda yang diolah menggunakan SPSS Versi 23.0 for windows. Adapun hasil analisis data dari penelitian ini:

$$
\mathrm{EK}=1,579+0,305 \mathrm{LKG}+0,321 \mathrm{KSJ}
$$

Persamaan regresi tersebut dapat diinterpretasikan sebagai berikut:

1. Nilai konstanta yang terdapat pada persamaan regresi tersebut adalah 1,579. Angka tersebut menunjukkan tingkat etos kerja pada karyawan PTPN I Pulau Tiga bila tingkat lingkungan dan kesejahteraan bernilai nol.

2. Nilai koefisien regresi variabel lingkungan (LKG) adalah 0,305 dan memiliki pengaruh positif yang artinya, apabila lingkungan mengalami peningkatan sebesar satu satuan maka etos kerja akan meningkat sebesar 0,309 satuan dengan asumsi variabel kesejahteraan tetap.

3. Nilai koefisien regresi variabel kesejahteraan (KSJ) adalah 0,321 dan memiliki pengaruh positif yang artinya, apabila kesejahteraan mengalami peningkatan sebesar satu satuan maka etos kerja akan meningkat sebesar 0,321 satuan dengan asumsi variabel lingkungan tetap.

\section{Pembuktian Hipotesis}

\section{Uji Signifikansi Parameter Individual (Uji}

t)

Menurut Supangat (2008), untuk mencari nilai $t_{\text {tabel, }}$ yaitu: $t_{\text {tabel }} \mathrm{df:} \alpha,(\mathrm{n}-\mathrm{k})=$ 0,05, Dimana: $\mathrm{n}=$ Jumlah responden, $\mathrm{k}=$ Jumlah variabel yang di uji. Maka df: $\alpha$, (563 ) adalah 2,005. Untuk mengetahui lebih jelas pengaruh parsial masing-masing variabel dapat dilihat pada Tabel 1.

Berdasarkan Tabel 1 tersebut dapat dijelaskan interpretasi dari masing-masing koefisien, yaitu sebagai berikut:

1. Variabel lingkungan memiliki nilai $t_{\text {hitung }}$ sebesar 2,144, sedangkan $t_{\text {tabel }}$ pada probabilitas 5\% adalah sebesar 2,005. Oleh karena itu pada perhitungan $t_{\text {hitung }}>$ $\mathrm{t}_{\text {tabel }}(2,144>2,005)$ dengan $\mathrm{t}$ signifikan $0,037<\mathrm{t}$ signifikan ketetapan 0,05, maka dapat dinyatakan bahwa secara statistik variabel lingkungan berpengaruh 
Tabel 1. Hasil Analisis Statistik

\begin{tabular}{lccc}
\hline Variabel & $\mathrm{B}$ & $\mathrm{t}$ & Sig. t \\
\hline Konstanta & 1,579 & & \\
Lingkungan & 0,305 & 2,144 & 0,037 \\
Kesejahteraan & 0,321 & 2,257 & 0,028 \\
\hline R. Square & $=0,314$ & & \\
F & $=12,140$ & & \\
Sig. F & $=0,000$ & &
\end{tabular}

Sumber: Data Primer diolah, 2017

signifikan terhadap etos kerja. Dengan demikian hipotesis dalam penelitian ini diterima.

2. Variabel kesejahteraan memiliki nilai $t_{\text {hitung }}$ sebesar 2,257, sedangkan $t_{\text {tabel }}$ pada probabilitas 5\% adalah sebesar 2,005. Oleh karena itu pada perhitungan $t_{\text {hitung }}>$ $t_{\text {tabel }}(2,257>2,005)$ dengan $t$ signifikan0,028 < t signifikan ketetapan 0,05, maka dapat dinyatakan bahwa secara statistik variabel kesejahteraan berpengaruh signifikan terhadap etos kerja. Dengan demikian hipotesis dalam penelitian ini diterima.

\section{Uji Signifikansi secara Simultan (Uji F)}

Oleh karena itu pada perhitungan $F_{\text {hitung }}>F_{\text {tabel }}(12,140>3,170)$ dengan $F$ signifikan $0,000<\mathrm{F}$ signifikan ketetapan 0,05, maka dapat dinyatakan bahwa secara statistik variabel lingkungan dan kesejahteraan secara simultan berpengaruh signifikan terhadap etos kerja. Dengan demikian hipotesis dalam penelitian ini diterima.

\section{Uji Koefisien Determinasi $\left(\mathbf{R}^{2}\right)$}

Nilai koefisien determinasi $\left(\mathrm{R}^{2}\right)$ adalah sebesar 0,314 atau $31,4 \%$. Hal ini menunjukkan bahwa kedua variabel bebas yang terdiri dari lingkungan dan kesejahteraan secara bersama-sama mampu menerangkan perubahan yang terjadi pada etos kerja sebesar $31,4 \%$ dan sisanya sebesar $68,6 \%$ dipengaruhi oleh variabel lain yang tidak diteliti dalam penelitian ini.

\section{KESIMPULAN}

Berdasarkan hasil penelitian dan pembahasan, maka dapat ditarik kesimpulan sebagai berikut:

1. Lingkungan secara parsial berpengaruh positif dan signifikan terhadap etos kerja pada karyawan PTPN I Pulau Tiga.

2. Kesejahteraan secara parsial berpengaruh positif dan signifikan terhadap etos kerja pada karyawan PTPN I Pulau Tiga.

3. Lingkungan dan kesejahteraan secara simultan berpengaruh positif dan signifikan terhadap etos kerja pada karyawan PTPN I Pulau Tiga.

4. Nilai koefisien determinasi sebesar 0,314 menjelaskan bahwa variabel lingkungan dan kesejahteraan mempengaruhi etos kerja pada karyawan PTPN I Pulau Tiga sebesar $31,4 \%$, sedangkan sisanya sebesar $68,6 \%$ dipengaruhi oleh variabel lain di luar model penelitian ini.

\section{Saran}

Saran yang dapat disampaikan dalam penelitian ini, yaitu sebagai berikut:

1. Pihak PTPN I Pulau Tiga sebaiknya ruang kantor diberikan penambahan fasilitas, seperti AC (Air Conditioner) dan kipas angin serta melakukan renovasi ruangan dan fasilitas-fasilitas yang masih bisa digunakan, sehingga dapat selalu berfungsi dengan baik agar para karyawan merasa nyaman saat bekerja. Kemudian pihak perusahaan sebaiknya mengadakan kegiatankegiatan khusus untuk karyawan bersama atasan agar dapat menjalin hubungan yang baik dalam bekerja dan menaikkan produktivitas kerja sehingga etos kerja karyawan juga ikut 
meningkat. Selain itu apabila lingkungan sudah tidak kondusif lagi, maka sebaiknya pihak perusahaan mencari lingkungan atau tempat yang lebih strategis lagi untuk dijadikan sebagai kantor PTPN I Pulau Tiga yang sedikit lebih jauh dari pabrik, sehingga karyawan tidak terkena polusi udara maupun polusi air yang berasal dari pabrik.

2. Sebaiknya pihak PTPN I Pulau Tiga juga lebih memperhatikan kesejahteraan karyawannya, yaitu dengan memberikan uang lembur yang sesuai dengan kesepakatan dan tepat waktu, memberikan perumahan kepada karyawan dengan layak dan strategis, penyediaan fasilitas air minum yang bersih harus diberikan dengan maksimal untuk kesehatan karyawan, kemudian pemberian dana pensiun sebaiknya ditingkatkan sesuai dengan kesepakatan bersama serta mengadakan programprogram rekreasi agar karyawan tidak merasa jenuh dan terus termotivasi untuk bekerja dengan baik.

3. Lingkungan dan kesejahteraan mempengaruhi etos kerja pada karyawan PTPN I Pulau Tiga sebesar 31,4\%, untuk itu pihak PTPN I Pulau Tiga perlu menganalisis variabel lainnya yang dapat mempengaruhi etos kerja pada karyawan, seperti kepuasan kerja, motivasi kerja, komunikasi, kemandirian, budaya kerja dan sebagainya.

\section{DAFTAR PUSTAKA}

Anoraga, Panji. 2009.Psikologi Kerja. Jakarta: Rineka Cipta.

Ghozali. 2011. Metode Penelitian. Yogyakarta: Andi Offset.

Ginting, Paham, dan Syafrizal Helmi Situmorang. 2008. Filsafat Ilmu dan MetodeRiset. Medan: USU Press.

Hasan, Iqbal. 2009.Analisis Data Penelitian dengan Statistika. Jakarta: Bumi Aksara.

Hasibuan, Malayu S.P. 2010.Manajemen Sumber Daya Manusia. Jakarta: Bumi
Aksara.

Heidjrachman, Ranupandojo, dan Suad Husnan. 2009. Manajemen Personalia. Yogyakarta: BPFE UGM

Hitt, A. Michael. 2009. Manajemen Strategis. Jakarta: Erlangga.

Husnan, Suad. 2010. Manajemen Personalia. Yogyakarta: BPFE UGM.

Isyandi, B. 2009. Manajemen Sumber Daya Manusia Dalam Perspektif Global. Pekanbaru: Unri Press.

Manullang, M. 2009. Manajemen Personalia. Jakarta: Ghalia Indonesia.

Mardiana. 2010. Manajemen Produksi. Jakarta: Badan IPWI.

Moekijat. 2010. Manajemen Sumber Daya Manusia. Bandung: Mandar Maju.

Mulyanto. 2008. Pengaruh Kepuasan Kerja, Motivasi dan Kesejahteraan terhadap

Etos Kerja Karyawan pada Badan Kepegawaian Daerah Kota Surakarta. Jurnal Excellent. Vol. 1. No. 2. Hal: 114.

Narimawati, Umi. 2008. Metodologi Penelitian Kualitatif dan Kuantitatif, Teori dan Aplikasi. Bandung: Agung Media.

Neufeldt, Victoria. 2010.Webster's New World Dictionary. New York: Webster's New World Dictionary.

Nitisemito, Alex. S. 2008. Manajemen Personalia. Edisi Kedua. Jakarta: Ghalia Indonesia.

Nuraini, T. 2013. Manajemen Sumber Daya Manusia. Pekanbaru: Yayasan Aini Syam.

Petty, Gregory C. 2008. Vocational-Tehnical Education and The Occupational Work Ethic. New York: MacGraw-Hill Inc.

Siagian, Sondang P. 2009. Manajemen Sumber Daya Manusia. Jakarta: Bumi Aksara.

Simanjuntak, Payaman J. 2008. Produktivitas Kerja Pengertian dan /ruang Lingkupnya. Jakarta: Prisma.

Sinamo, Jansen. 2011. 8 Etos Kerja Profesional. Jakarta: Institut Dharma Mahardika.

Sugiyono. 2008. Metode Penelitian Kuantitatif, Kualitatif dan R\&D. 
Bandung: Alfabeta.

Supangat, Andi. 2008. Statistik dalam

Kajian Deskriptif, Infensi dan

Paramatik. Jakarta: Kencana Prenada.

Suwatno, dan Priansa, Donni Juni. 2011.

Manajemen Sumber Daya Manusia

dalam Organisasi Publik dan Bisnis.

Bandung: Alfabeta.

Tanjungsari. 2011. Pengaruh Kemandirian,
Lingkungan dan Kesejahteraan terhadap

Etos Kerja Karyawan PT. Tirta Investama di Klaten. Jurnal Excellent. Edisi 1. No. 1. Hal: 1-20.

Umar, Husein. 2009. Riset Sumber Daya

Manusia dalam Organisasi. Jakarta:

Gramedia Pustaka Utama.

Wursanto. 2009. Dasar-dasar Ilmu

Organisasi. Yogyakarta: Andi Offset. 